九州大学学術情報リポジトリ

Kyushu University Institutional Repository

\title{
On Some Deep-Sea Angler-Fishes Obtained In Sagami Bay And Suruga Bay
}

Imai, Sadahiko

Department of Agriculture, Kyusyu Imperial University

https://doi.org/10.5109/22595

出版情報 : 九州大学大学院農学研究院紀要. 7 (2)，pp.37-48，1942-09. Kyushu Imperial University バージョン：

権利関係 : 


\title{
ON SOME DEEP-SEA ANGLER-FISHES OBTAINED IN SAGAMI BAY AND SURUGA BAY"
}

\author{
Sadahiko IMAI
}

The present paper deals with some deep-sea angler-fishes obtained mainly by the collecting boats of the Mitsui Institute of Marine Biology, in Sagami Bay and Suruga Bay during a period terminating in the winter of 1941.

The author examined eight specimens of the fishes in all; four of them were collected by the boats of the Institute, the "Sanken-Maru" and the "Tumeki-Maru", and four of them were kindly offered to the "Tumeki-Maru" by Mr. NoDA, the skipper of a trawler of Heda, "Dainiti-Maru". The deep-water hauls of the "Sanken-Maru" and the "Tumeki-Maru" have been carried out in Sagami Bay and Suruga Bay at several stations about $800 \mathrm{~m}$ or more in depth. Three kinds of nets, a $1 \mathrm{~m}$ circular net and two beam trawls with $1.5 \mathrm{~m}$ and $4 \mathrm{~m}$ long beams respectively, were used for the hauls. The length of wire released for the trawling was usually $1500 \mathrm{~m}$, but sometimes it extended up to $1800 \mathrm{~m}$, so that the fishes from surface to the depths of about 500 to $900 \mathrm{~m}$ must have been caught in the nets, according to the length of wire. The "Dainiti-Maru" works for the shrimps and deep-sea fishes on the slope of the north-eastern part of Suruga Bay. The depth exceeds $1000 \mathrm{~m}$ there, being only 4 miles or so

\footnotetext{
1) Contributions from the Institute of Scientific Fisheries, Department of Agriculture, Kyüsyü Imperial University, No. 4.
} 
off the shore, and consequently inhabitants of deeper waters would frequently come out among the catches of the trawler.

The specimens are rather small and were more or less damaged before being hauled up on board, probably because of the small size of the nets. It is difficult therefore, in some specimens, to make a specific distinction of them accurately, but it is most likely that they belong to six species as listed below, distributed among three families of Ceratioidea, namely Ceratiidae, Oneirodidae and Linophrynidae.

Family Ceratiidae

Cryptosparas normani REGAN and TREWAVAS

Cryptosparas couesi GILL

Mancalias uranoscopus YARRELL

Mancalias sessilis IMAI

Family Oneirodidae

Chaenophryne macractis REGAN and TREwAVAS

Family Linophrynidae

Linophryne densiramus IMAI

Of the fishes listed above, $M$. sessilis and $L$. densiramus were dealt with in the recent paper of the author, and no specimens have since been obtained; $C$. couesi has recently recorded by Dr. M. ÔsHIMA from Japan Sea; the other three species are recorded for the first time from Japan in the present paper. All the specimens are deposited in the Institute.

Three more deep-sea angler-fishes were recorded previously from Japan, namely Cryptosparas mitsukurii (TANAKA), Cryptosparas carunculatus (GÜNTHER) and Himantolophus grönlandicus RHEINHARDT. But the author has not examined them except a specimen of the last-named species, so that no more descriptions can be added here about them.

The author is much indebted to Mr. Takanaga Mirul, the founder of the Mitsui Institute of Marine Biology, for affording me the facility of the study, and to Dr. I. Amemiya, the Director of the Institute, for his constant guidance. 


\section{Family Ceratiidae \\ Cryptosparas GILL}

1. Cryptosparas normani REGAN and TREWAVAS

Japanese name: Norman-Oki-Ankô

(Figs. 1 and 2)

Cryptosparas couesi NoRMan, Discovery Report, no. 2, 1930, p. 354, fig. 44

Cryptosparas normani REGAN and TREwAVAS, the Carlsberg Foundation's Oceanographical Expedition round the World 1928-30, Report No. 2, 1928, p. 98

D. 4 ; A. 4 ; P. 16 ; C. 8 . Head $1.9(1.8)$ in length without caudal fin, depth of body $2.3(2.4)$, breadth of body $4.7(3.6)$; snout 3.1 in head, interorbital space $3.9(3.8)$, length of upper jaw 2.8 (2.2); eye $11.1(10.2)$ in snout.

Body moderately compressed. Back arched; head truncated, its anterior profile, consisted of lower jaw, directing forward and slightly downward; the ventral contour rendering a gradually ascending line to anal fin. Mouth-cleft vertical; lower jaw shorter than the upper and included in it; symphysis provided with a blunt tubercle; the anterior tip of maxillary concealed. Teeth rather small; on premaxillary, 7 small canine arranged in a series; several longer canines situated behind some anterior teeth of the

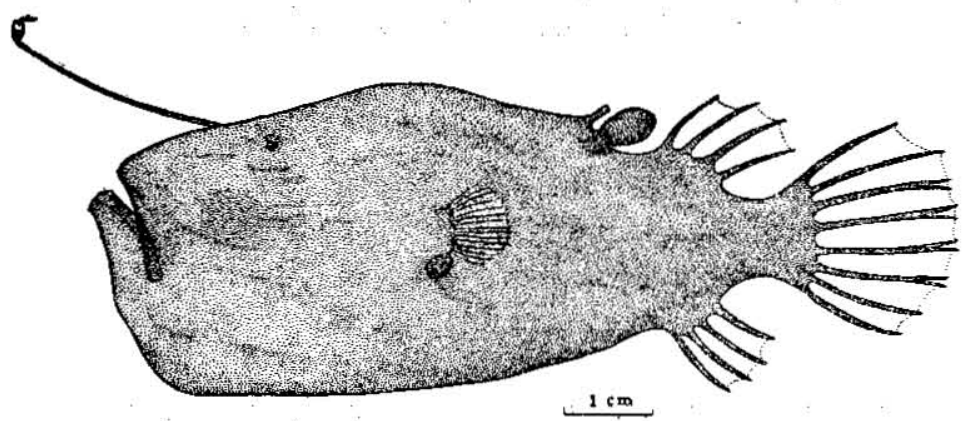

Fig. 1.-Cryptosparas normani Rrgan and TREwaVAs.

series; on mandible in 2 irregular series anteriorly and in a series posteriorly, about 10 canines in the outer series and 6 in the inner; vomer with 4 teeth on each side; palatines and tongue toothless. Eye extremely small; illicium originating from a deep groove above eye, the distance from snout to its origin $2.4(2.0)$ in 
head; the basal bone slender, 3.0 in length of body, and connecting to the bulb with very short stem; the bulb oval, about twice as large as eye, pigmented proximally, involving a black body; the body divided to both sides with unpigmented interspaces widening distally, and provided with a notch at tip on each side; an $\mathrm{H}$-shaped deeply pigmented eminence on top of the bulb, a distal filament originating between its parallel bars, provided with a pair of short branches directed to both sides, the branches becoming more multiplied and shortened distally like a tuft in general appearance. Gill-opening inserted halfway between back and belly, its diameter about 9.4 in head, partly covered with pectoral fin. One median and a pair of lateral caruncles situated before dorsal fin, all pyriform in shape and each with a pore at tip, median caruncle larger than lateral, its height 6.5 in head; lateral ones about half of its size. A tube-like process originating from just before median caruncle; its length nearly equal to height of the caruncle. Dorsal and anal fins matched in their size and situation; the distance from snout to origin of dorsal 1.3 in length of body, its base 3.4; its height about one-fourth (higher in the smaller specimen) of head; anal originating slightly behind dorsal, and with a little shorter base and rays. Pectoral fin situated just above gill-opening; its length less than one-sixth of head. Caudal peduncle rather short; its depth about a quarter (one-third in the smaller specimen) of depth of body. Caudal fin well developed, with rounded margin; median 4 rays diverged distally, and without bulb-like organ at tip.

Minute granules, changing to spinules on back, scattered over head and body except lips, basal bone of illicium and the groove for it, tops of the dorsal caruncles and the process before them.

Colour uniformly jet-black, basal bone of illicium and rays of pectoral fin pale, mouth cavity whitish with dusky area.

Two specimens have been examined: about $90(75+$ about 15$)$ mm long, collected by the "Dainiti-Maru" and presented to the Institute on 27th of April, 1939; and $47(36+11) \mathrm{mm}$ long also from Suruga Bay, $35^{\circ} 00^{\prime} \mathrm{N}$, $138^{\circ} 38^{\prime} \mathrm{E}$, by the use of a $4 \mathrm{~m}$ beam trawl with $1500 \mathrm{~m}$ wire, on 21st of October, 1940 . The above description is based on the larger specimen, while the characters of the smaller one are added in brackets. The illicium of the 
latter specimen was unfortunately torn off before being hauled up on board.

REGAN and Trewavas separated the present species from $C$. couesi, based on a specimen from South Atlantic, by reason of the fact that the former had a short papilla-like process before caruncles. The specimens before me agree well with theirs in this respect. But with regard to the bulb of illicium, nevertheless no difference about this organ is mentioned by REgAN and TREwAVAS to be found

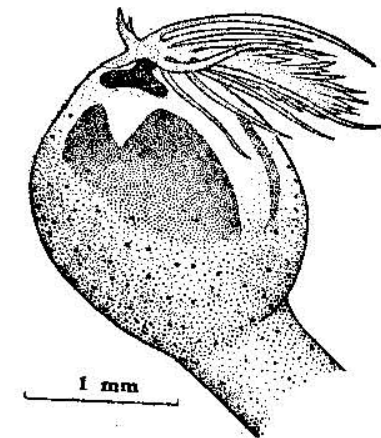

Fig. 2.-Cryptesparas normani. Bulb of illicium. between the two species named, it differs from the one in C. conesi of the same size, where the organ in question is provided with a simple branched distal filament. And on the other hand, it resembles closely to the corresponding organ in C. mitsukurii of Japan, the species known only by the type $440 \mathrm{~mm}$ in total length, in which it consists of 'a pear-shaped bulb and a terminal tuft' ${ }^{\prime \prime}$. In addition to this, in $C$. mitsukurii, the dorsal process is developed to a long tentacle-like tube, a little shorter than premaxillary, while $C$. couesi has no such process even a large specimen. In our specimens, one of which is about twice as large as the other, the process does not differ conspicuously in length between the two, so that it is not likely that it increases in length with growth of body. "But if the long tentacle-like process in the type of C. mitsukurii were due to the extraordinary size of the animal, the specimen here dealt with may rather belong to that species than to $C$. normani.

Except $C$. couesi, these fishes have hitherto been represented by a few specimens, collected namely: two of C. normani, from Atlantic, one of which by the "Discovery", the other by the "Arctulus", and a single C. mitsukurii from Sagami Bay. The relations between these species will be made clear when several more specimens of various size are obtained.

1) Tanaks, S. Figures and Descriptions of Fishes of Japan, 1911, p. 30, pl. 8, fig. 25. 


\section{Cryptosparas couesi Gill}

\section{Japanese name: Oki-Ankô}

(Fig. 3)

Cryptosparas couesi Goode and BeAN, Oceanic Ichthyology, 1896, p. 491, fig. 402; JorDAn and Evermani, Fishes of North and Middle America, vol. 3, 1898, p. 2731, fig. 956; RgGAN, the Danish Dana Expedition 1920-22, Report No. 2, 1926, p. 35; Regan and TrEwayas, the Carlsberg Foundation's Oceanographical Expedition round the World 1928-30, Report No. 2, 1932, p. 96, fig. 154, ÔsHma, Rec. Oceanogr. Works Japan, vol. 6, 1934, p. 108, fig.

Ceratias couesi Brauer, 'Valdivia' Tiefseefische, 1906, p. 317, pl. 15, fig. 7.

D. 4 ; A. 4 ; P. 16 ; C. 8 . Head 1.8 in length without caudal fin, depth of body 2.1, breadth of body 4.8 ; snout 2.0 in head, length of upper jaw 2.4; diameter of eye 8.0 in snout.

Closely resembling $C$. normani in general appearance. Basal bone of illicium 2.1 in length of body, originating from a little before eye, the distance from snout to its origin 2.4 in head; bulb of illicium oval with short stem; its length about one and a half times of eye, bearing a black body inside; a pair of pigmented ridges on its distal end, a slight prominence arising between them. The distance from snout to origin of dorsal fin 1.2 in length of body, anal situated immediately below it, the height of the fins nearly equal, about 4.0 in head. One median and a pair of lateral caruncles on back before dorsal fin, the former about half of the fin in height. No process or prominence before the caruncles.

Skin covered with fine granules except on lips, the groove above head, illicium and its basal bone.

Colour generally jet-black, basal bone of illicium slightly pigmented, mouth cavity whitish.

Described from a specimen, $23(17+6) \mathrm{mm}$ in total length, collected from Suruga Bay, $35^{\circ} 00^{\prime} \mathrm{N}, 138^{\circ} 38^{\prime} \mathrm{E}$, by the use of $4 \mathrm{~m}$ beam trawl with $1500 \mathrm{~m}$ wire, on $21 \mathrm{st}$ of October, 1940 .

The specimen well agrees with $C$. conesi of the same size except the fact that the bulb of illicium has no filament at tip, while in a specimen of $C$. couesi of $25 \mathrm{~mm}$ long or so the organ is conspicuous according to REGAN and TREWAVAS. In this respect it rather resembles $C$. carunculatus, another Ceratioid fish from Japan, which is characteristic in having a small papilla on the bulb representing the distal filament in $C$. couesi, but having 
shorter basal bone of illicium and fewer pectoral rays as compared with other Cryptosparas. It is not clear, from lack of specimens, whether the filament on the bulb and the process in front of dorsal caruncles are actually present or not in C. normani and C. mitsukurii of such small size, so that the specimen before me may possibly represent the young form of one of these species.

C. couesi is widely distributed in Atlantic, Indian and Pacific Oceans. In vicinities of Japan, several specimens were collected from east of Formosa and one from Japan Sea, the latter, according to Dr. ÔsHIMA, reaching $220 \mathrm{~mm}$

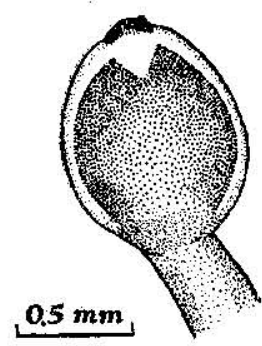

Fig. 3.-Cryptosparas couesi, Bulb of illicium, lateral view. in total length and having two or three filaments at tip of the bulb. C. carunculatus is known only by a specimen collected from south of Yedo by the "Challenger" a long time ago.

\section{Mancalias GILL}

\section{Mancalias uranoscopus MurRaY} Japanese name: Biwa-Ankô

(Figs. 4 and 5$)$

Ceratias uranoscopus Günther, 'Challenger' Deep-sea Fishes, 1898, p. 54, pl. 11, fig. C Mancalias uranoscopus Gond: and BEAN Oceanic Ichthyology, 1896, p. 490, fig. 601; REGAN, the Danish Dana Expedition 1920-22, Report No. 2, 1926, p. 37, fig. 21; REgAN and Trewavas, the Carlsberg Foundation's Oceanographical Expedition round the World 1928-30, Report No. 2, 1932 p. 99, fiig. 158.

Myosparas myops Gnbert, the Aquatic Resource of the Hawaiian Islands, the Deep-Sea Fishes, 1905, p. 694, pl. 99.

D. 4 ; A. 4 ; P. 17 (16); C. 8 . Head 2.3 in length without caudal fin, depth of body 2.7 (2.5), breadth of body $5.5(5.0)$; snout $2.6(2.5)$ in head, interorbital space 3.8(3.7), length of upper jaw 2.3 (2.5); diameter of eye $6.9(6.7)$ in snout.

Body more or less compressed, the anterior profile, consisting of lower jaw, nearly vertical; the dorsal and ventral contours generally arched to caudal peduncle; the whole body looking like a lute. The upper profile of the snout slightly concave. Cleft of mouth nearly vertical, the lower jaw included in the upper, and 
its lower surface directed forward and slightly downward; the anterior tip of maxillary pointed like a spine, symphysis provided with a pointed tip directed obliquely downward. Teeth on premaxillary arranged in irregular series, the anterior of them being enlarged, but far smaller than on mandible. Mandibular teeth depressible, arranged in ill-defined double series anteriorly, and in irregular single series posteriorly; about 20 in the outer series

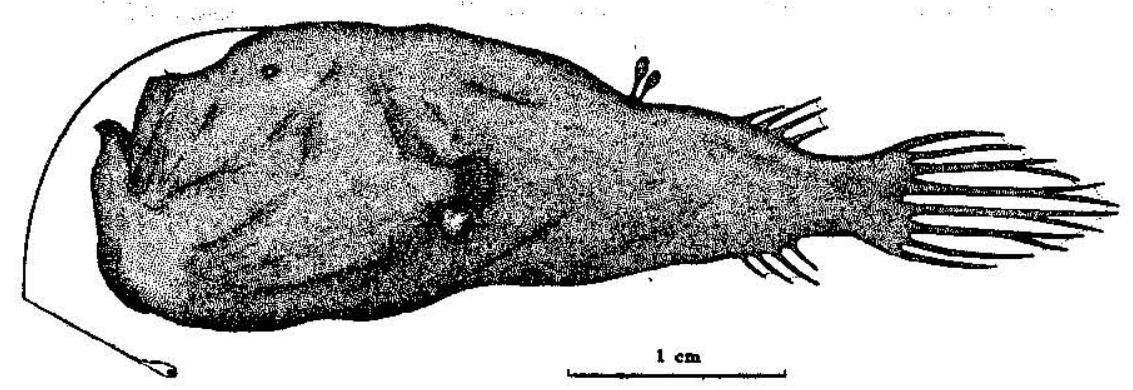

Fig. 4.-Mancalicis uranoscopus Murrar.

and 7 in the inner series; the inner teeth enlarged, the anterior one of them about one-sixth of snout in length, the outer teeth slightly enlarged posteriorly; all teeth canine-shaped. Eye extremely small. Illicium originating from a groove a little above and behind eye, the distance from snout to it 2.1(2.3) in head; the basal bone long and slender, $1.9(1.7)$ in length of body. The stem more slender, a little longer than one-third of it, swelling distally into a small oval bulb; its length about one-sixth of the stem (one-third in the smaller specimen), involving a black globular body near tip. A pair of stalked caruncles inserted before dorsal fin, its distance from tip of snout 1.6(1.6) in length of body, its length about half the height of dorsal fin, and the stem occupying more than half of it; the bulb pear-shaped, with a pore at tip. Dorsal fin situated well back, nearly opposite to anal, the distance from snout to its origin 1.4 (1.3) in length of body, the base 4.5(4.5); the height 3.4(3.8) in head; anal fin well matched with it both in situation and size. Pectoral fin small, 8.6 in length of head, originating about midway between back and belly, partly covering the upper margin of gill-opening. Caudal fin well de- 
veloped, its length about a quarter of body, its margin rounded; median 4 rays diverged distally.

Minute spinules covering head and body except lips, illicium, its basal bone and the groove on head.

Colour jet-black in fresh state, basal bone of illicium brownish black proximally and becoming paler distally, illicium pale.

Two specimens have been examined, $83(67+16) \mathrm{mm}$ and $46(35+11) \mathrm{mm}$ in total length; both specimens were collected by the "Dainiti-Maru". The above description is based on the larger specimen, characters of the smaller specimen being added in the brackets.

These specimens well agree with the above named species in every respect

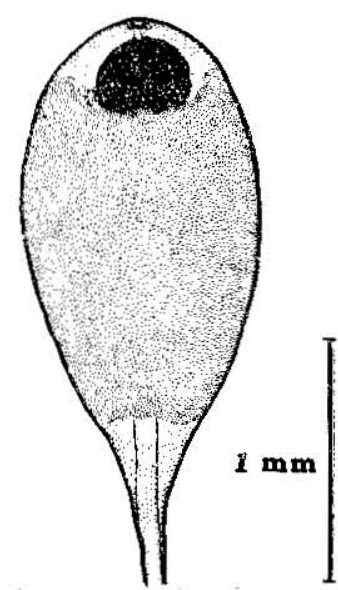

Fig. 5.-Mancalias uranoscopus.

Bulb of illicium, lateral view. except that the stem of illicium is gradually swollen distally forming the bulb, and the border between them is not so distinct as shown in the figure by REGAN and TREWANAS.

The present species is widely distributed in the world, and is known from the Atlantic, Caribbean Sea, Indian Ocean, South China Sea and so on. In the Pacific it was recorded from near Kauai, Hawaiian Islands, under the name of Myosparas myops, which is, according to REGAN and TrEwAVAS, identical with the present species.

\section{Mancalias sessilis IMAI}

Japanese name: Enasi-Biwa-Ankô

Mancalias sessilis Imar, Japan. Jour. Zool. vol. 9, no. 2, 1941, p. 245, fig 12.

D. 4 ; A. 4 ; P. 16 ; C. 8 . Head 1.5 in length without caudal fin, depth 3.8 , breadth 7.6 ; interorbital space 2.4 in head, snout 2.2 , length of upper jaw 2.2 ; eye 7.2 in snout.

A single specimen $36(28+8) \mathrm{mm}$ in total length was hauled 
from Sagami Bay, east of Hasima; by $1 \mathrm{~m}$ circular net with $1220 \mathrm{~m}$ wire, on 14th of November, 1937.

The present species is separated from other fishes of the genus chiefly in having the caruncles directly attached to back, without a stalk at its base.

Family Oneirodidae

Chaenophryne REGAN

5. Chaenophryne macractis REGAN and TREWAVAS

Japanese name: Rakuda-Ankô

(Figs. 6 and 7 )

Chaewophryne macractis RegAN and TrEWAVAs, the Carlsberg Foundation's Oceanographical Expedition round the World 1928-30, Report No. 2, 1932, p. 88, fig. 142.

D. 4 ; A. 4 ; P. 14 ; C. 8 . Head 1.7 in length without caudal fin, depth of body 2.1 , breadth of body 2.5 ; interorbital space 2.4 in head, length of premaxillary 1.6; diameter of eye 10.0 in snout.

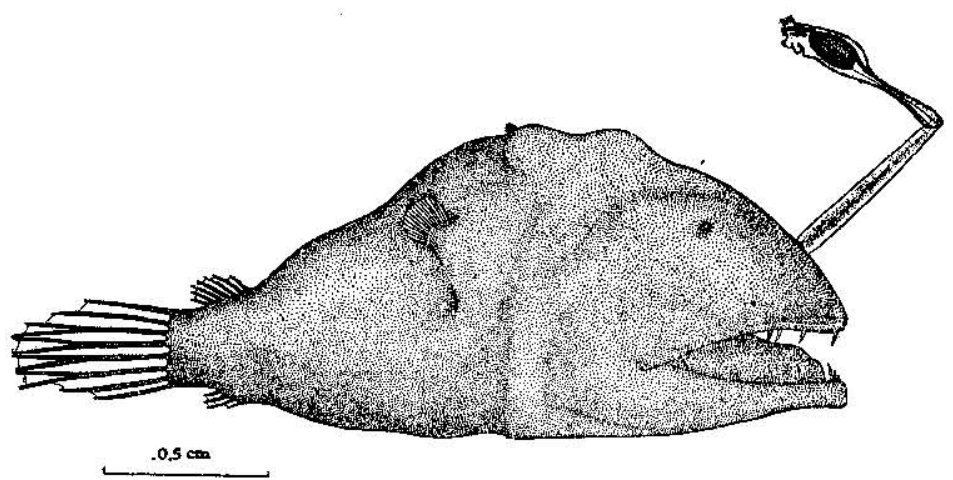

Fig. 6. - Chaenophryne macractis Regan and TRFwavas

Body moderately compressed. The dorsal contour highly arched to the two rounded humps consisting of the ridges of parietal and postotemporal; the back between the ridges of each side rather deeply concave and this hollow reaches nearly to back of snout. The ventral contour making almost a horizontal line to anal fin. Eye extremely small, about one-nineth of snout. Cleft 
of mouth horizontal, both jaws nearly of equal length. Teeth canineshaped, 5 on premaxillary, and 6 on mandible; mandibular teeth longer than those of premaxillary, the longest of them being about one-fifth of snout, the anterior 4 of them with an auxiliary tooth behind each. An erect tooth on cach side of vomer; palatines and tongue toothless. The illicium club-shaped, its length 3.0 in length of body, the distal half swollen and containing a black oval body inside; a black rod-lijke projection enclosed in a transparent sheath, with a pigmented prominence proximally, arising from the distal side of the body and extending obliquely upward and backward; another projection originating from the proximal end of the body, extending downward, and ending in a colourless tip; a transparent appendage growing behind the distal projection, provided with a pair of wings extending anteriorly, and spit into 7 or 8 fringes at tips, and holding the anterior projection between
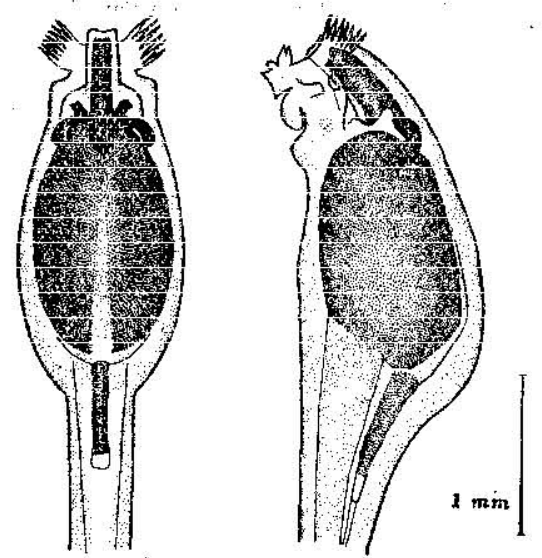

Fig. 7--Chaenophryne macractis. Bulb of illicium, left: anterior view, right: lateral view.

them. The basal bone of illicium robust, 2.9 in length of body, originating from about middle of snout, the distance from snout to its origin 4.8 in head. Gill-opening 8.2 in head, situated nearly halfway between back and belly. Pectoral fin small, originating above the central line of body, its length 9.0 in head. Dorsal and anal also small, both situated near tip of body. Caudal fin well 
developed, with rounded margin; median 4 rays diverged distally.

The skin smooth, without spinules or tubercles.

Colour jet-black in most part of body; basal bone of illicium slightly pigmented, the illicium whitish except the pigmented bodies.

The description is based on a specimen $25(20+5) \mathrm{mm}$ long, collected from Sagami Bay, $35^{\circ} 02^{\prime} \mathrm{N}, 139^{\circ} 15.5^{\prime} \mathrm{E}$, by $4 \mathrm{~m}$ beam trawl with $1800 \mathrm{~m}$ wire, on 17th of January, 1941.

The specimen tallies on the whole with the original description of the type. It can be distinguished from any of the allied species mainly in the shape of bulb of barbel, and particularly in this respect, our specimen agrees well with the species named, although there are some minute points which are more or less different.

A single specimen, $20(15+5) \mathrm{mm}$ in total length, was previously taken from the Pacific, between Galapagos and Marquesas Islands.

Family Linophrynidae

Linophryne COLLET

6. Linophryne densiramus IMAI

Japanese name: Oni-Ankô

Linophryne densiramus Imal, Japan. Jour. Zool,, vol. 9 no. 2, 1941, p. 247, fig 14.

D. 3 ; A. 3 ; P. 14 ; C. 8 . Head 1.8 in length without caudal fin, depth of body 2.6 , breadth of body 7.8 ; eye 7.5 in head, snout 2.7, interorbital space 3.8 , length of upper jaw 1.6.

A specimen $70(50+20) \mathrm{mm}$ long was collected by the "DainitiMaru".

The present species is separated from related species mainly in the following points: 1 . having a short appendage on bulb of illicium in front of the trifid one. 2. the presence of branches originating from the posterior appendage on the bulb. 3 . having 2 pairs of main branches of barbel instead of one pair. 